\title{
Coastal cliff at Lenzer Bach on Jasmund Peninsula, Rügen Island (Pleistocene Stripe 4): reconstructed history of glacitectonic deformation based on fold geometry and microstructural mapping
}

\author{
Paul Mehlhorn $^{1}$, Laura Winkler ${ }^{1}$, Franziska-Charlotte Grabbe ${ }^{1}$, Michael Kenzler ${ }^{1}$, Anna Gehrmann ${ }^{1}$, \\ Heiko Hüneke $^{1}$, and Henrik Rother ${ }^{1,2}$ \\ ${ }^{1}$ Institute for Geography and Geology, University of Greifswald, Greifswald, 14789, Germany \\ ${ }^{2}$ Landesamt für Geologie und Bergwesen Sachsen-Anhalt (LAGB), State Geological Survey Saxony-Anhalt, \\ Köthener Str. 38, 06118 Halle, Germany
}

Correspondence: Paul Mehlhorn (paul.mehlhorn@uni-greifswald.de)

Relevant dates: $\quad$ Published: 15 August 2019

How to cite: $\quad$ Mehlhorn, P., Winkler, L., Grabbe, F.-C., Kenzler, M., Gehrmann, A., Hüneke, H., and Rother, H.: Coastal cliff at Lenzer Bach on Jasmund Peninsula, Rügen Island (Pleistocene Stripe 4): reconstructed history of glacitectonic deformation based on fold geometry and microstructural mapping, DEUQUA Spec. Pub., 2, 35-41, https://doi.org/10.5194/deuquasp-2-35-2019, 2019.

Abstract:

\begin{abstract}
A thrust-bound footwall syncline located within the proximal part of the southern Jasmund Glacitectonic Complex is investigated, exploring the spatio-temporal relationship between glacitectonic macro- and microstructures. Orientation and geometry of macroscale folds and thrust faults reveal a two-phased deformation history recorded by the sedimentary sequence. The deformation is a result of glacitectonic imbrication and subsequent ice flow across Jasmund Peninsula during the late Weichselian. Clast microfabrics preserved within the folded glacial diamicts reveal that till-internal deformation is mainly related to subglacial shearing within the glacier bed, which predates large-scale imbrication and folding.
\end{abstract}

\section{Introduction}

The syncline of Pleistocene Stripe 4 (Streifen 4) is located at a coastal cliff section northeast of Lenzer Bach near the town Sassnitz $\left(54^{\circ} 31^{\prime} 42.24^{\prime \prime} \mathrm{N}, 13^{\circ} 40^{\prime} 25.99^{\prime \prime} \mathrm{E}\right)$. The exposed sequence comprises tightly folded units of Upper Cretaceous chalk and (para-)conformably overlying Pleistocene sediments, comprising glacial diamicts (till units M1 and M2) and interbedded gravel, sand and silt (units I1 and I2) (Fig. 1). Above an angular unconformity, which truncates the large-scale glacitectonic structure, gravel-rich channel fills and a further glacial diamict (M3 unit) are deposited. Optically stimulated luminescence (OSL) dating supported by lithostratigraphic correlation indicates that the Pleistocene succession was mainly formed during the Weichselian advance of the Scandinavian Ice Sheet (see Kenzler et al., 2017; Kenzler and Hüneke, 2019).

Over the last century the locality at Stripe 4 has been investigated multiple times with a focus on reconstructing the depositional history and entangling the site's spectacular but complex glacitectonic history (e.g. Keilhack, 1914; Jaekel, 1917; Steinich, 1972; Kahlke, 1982). Based on ar- 


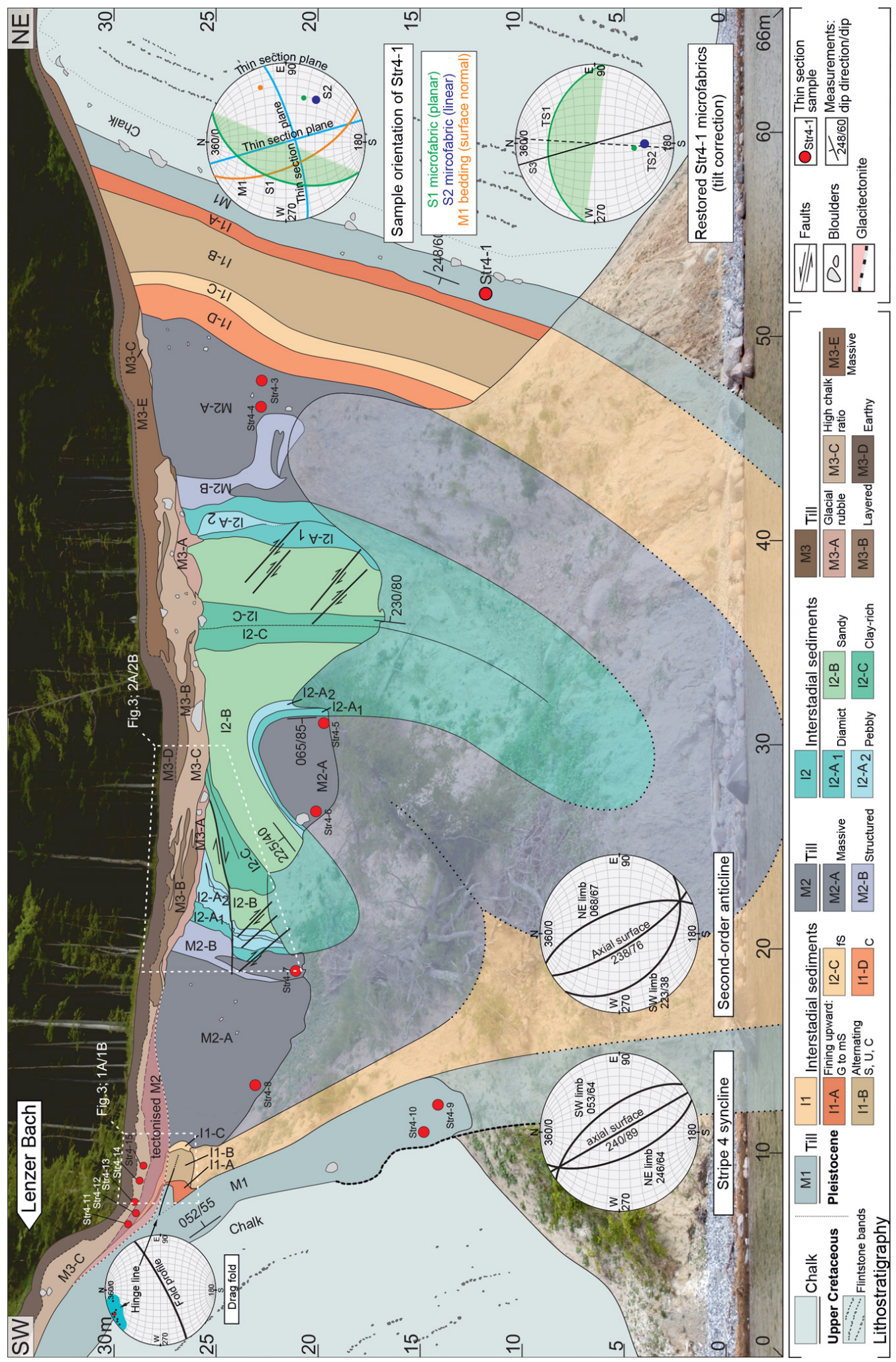

Figure 1. Geological cliff section of Pleistocene Stripe 4 (Streifen 4) northeast of Sassnitz on Rügen Island (Mehlhorn, 2016, modified), showing large-scale glacitectonic folding of Cretaceous chalk and Pleistocene glacial deposits of units M1 to I2, as well as the unconformably overlying late Weichselian M3 sediment complex. Structural data and sample locations from which thin sections were produced for clast microfabric analyses are indicated (red dots). Lower-hemisphere stereographic plots highlight orientation of the macroscopic folds (left) and results from the clast-microfabric analysis (right). Note that the coastal cliff is oriented almost perpendicular to the strike of the fold structures. 


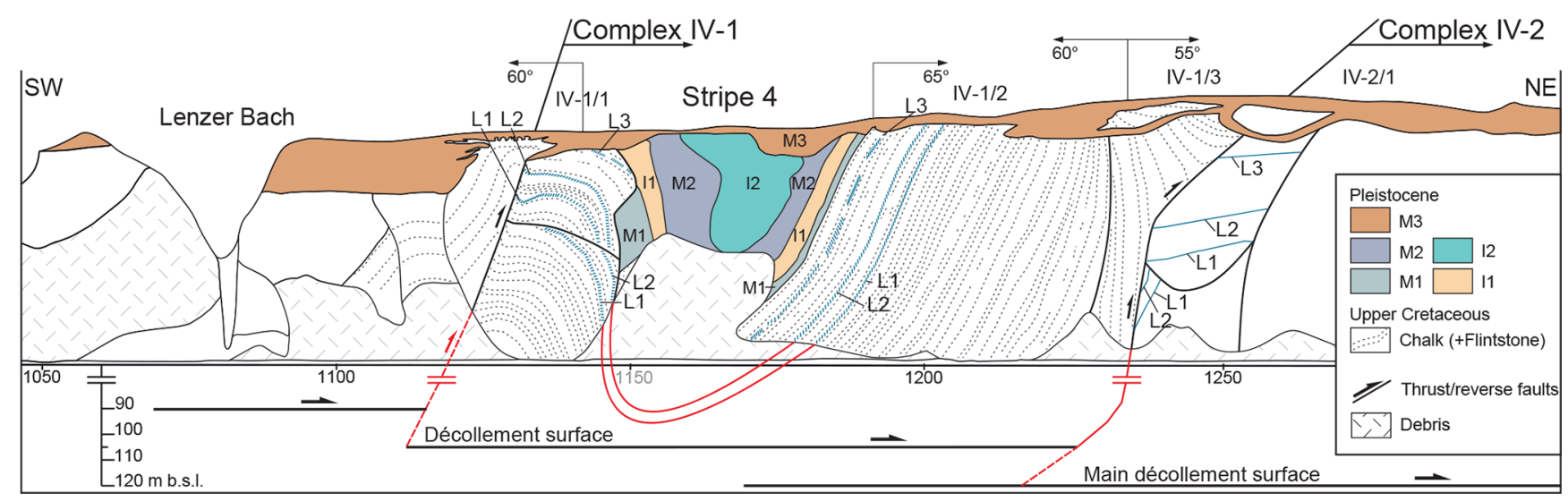

Figure 2. NE-verging syncline of Pleistocene Stripe 4 within a framework of imbricate thrust sheets exhibiting hanging-wall anticlines of chalk (based on Steinich, 1972, and Gehrmann, 2018). The depicted depth of the decollement (at 105-120 m b.s.1.) is not true to scale. Black dashed lines indicate flint layers. See Fig. 1 for stratigraphy of the Pleistocene units.

chitectural geometries, recognition of crosscutting relationships between the depositional units and identification of glacitectonic structures, an imbricate thrust-stack model was eventually developed for the glacitectonic evolution of the Jasmund Peninsula during the Weichselian glaciation (e.g. Steinich, 1972; Groth, 2003; Ludwig, 2011). More recently, Gehrmann and Harding (2018) and Gehrmann (2018) classified this area as a glacitectonic complex, where Stripe 4 is in a proximal position within the southern structural sub-complex of the overall Jasmund Glacitectonic Complex. The Pleistocene succession is preserved in the footwall syncline between the hanging-wall anticlines of two adjoining imbricate thrust sheets, which are separated by a steep ramp (Fig. 2).

In early 2012, a cliff failure formed a new exposure that exhibited the fold in modified geometry and detail including a metre-scale second-order parasitic fold at the centre of the syncline and a drag fold at its southern limb (Fig. 1). These circumstances allowed for a new in-depth macro- and microstructural investigation (Mehlhorn, 2016). The analysis of microstructures observed in thin sections from the glacial diamicts provided a relative chronology of deformational events, which is interpreted in the context of syn-depositional till-formation processes and post-depositional modifications (e.g. water escape, glacitectonic folding and imbrication) (Mehlhorn, 2016; Winkler, 2016; Grabbe, 2017). Note that all measurements of planes indicate direction and inclination of the dip.

\section{Macro- and microstructural characteristics}

\subsection{Northeast-verging syncline and second-order anticline below the angular unconformity}

The syncline comprises chalk beds and overlying Pleistocene deposits including units M1 to I2 (Fig. 1). The easily visible flint layers within the chalk allow for tracing of the deformed bedding and outline large-scale fold structures (Fig. 2). Fold axes and axial plane of the slightly asymmetric (tight) syncline strike NW-SE as documented by the orientation of bedding planes at both outer limbs $(246 / 64,053 / 64)$. Compared to the southwestern limb the northeastern limb dips distinctly steeper. The intersection point of the bedding-plane great circle (linear 330/13) indicates a gently plunging fold axis towards the NW. At the contact between the chalk and the Pleistocene units at the southwestern limb, we note some dislocation along an indistinct fault that runs along the stratigraphic boundary.

The southwestern limb of the syncline is characterised by a second-order fold (parasitic fold) that can be classified as an adventive anticline. It displays a distinct NE vergence, as documented by bedding-plane measurements within the I2 unit at both limbs (Fig. 1). The southwestern limb of the anticline dips at a low angle towards the SW (223/38), while the northeastern limb dips at a steeper angle towards the NE (068/67). The intersecting great circles of the bedding planes indicate a SE-directed plunge of the fold axis (linear 150/14). Thus, the fold axes of the main syncline and the second-order anticline plunge in opposite directions.

Within the southwestern limb of the syncline - above the parasitic anticline - the M2 and I2 units are offset by a flat SW-dipping reverse fault (Fig. $32 \mathrm{~A} / 2 \mathrm{~B}$; compare to Fig. 1) along which the hanging wall displays a NE-directed displacement of about $2 \mathrm{~m}$. Smaller-scale associated subordinate normal faults within the $\mathrm{I} 2$ unit show minor displacements of $5-10 \mathrm{~cm}$.

\subsection{Drag fold associated with the angular unconformity}

Along the above-mentioned angular unconformity near the top of the folded sequence, the chalk and Pleistocene units M1 to I2 are sharply truncated. An exception is a metre-scale (recumbent) drag fold at the southwestern limb of the syncline (Fig. 3 1A/1B, compare to Fig. 1). The subvertically oriented units M1, I1 and M2 are bent at right angles at their 


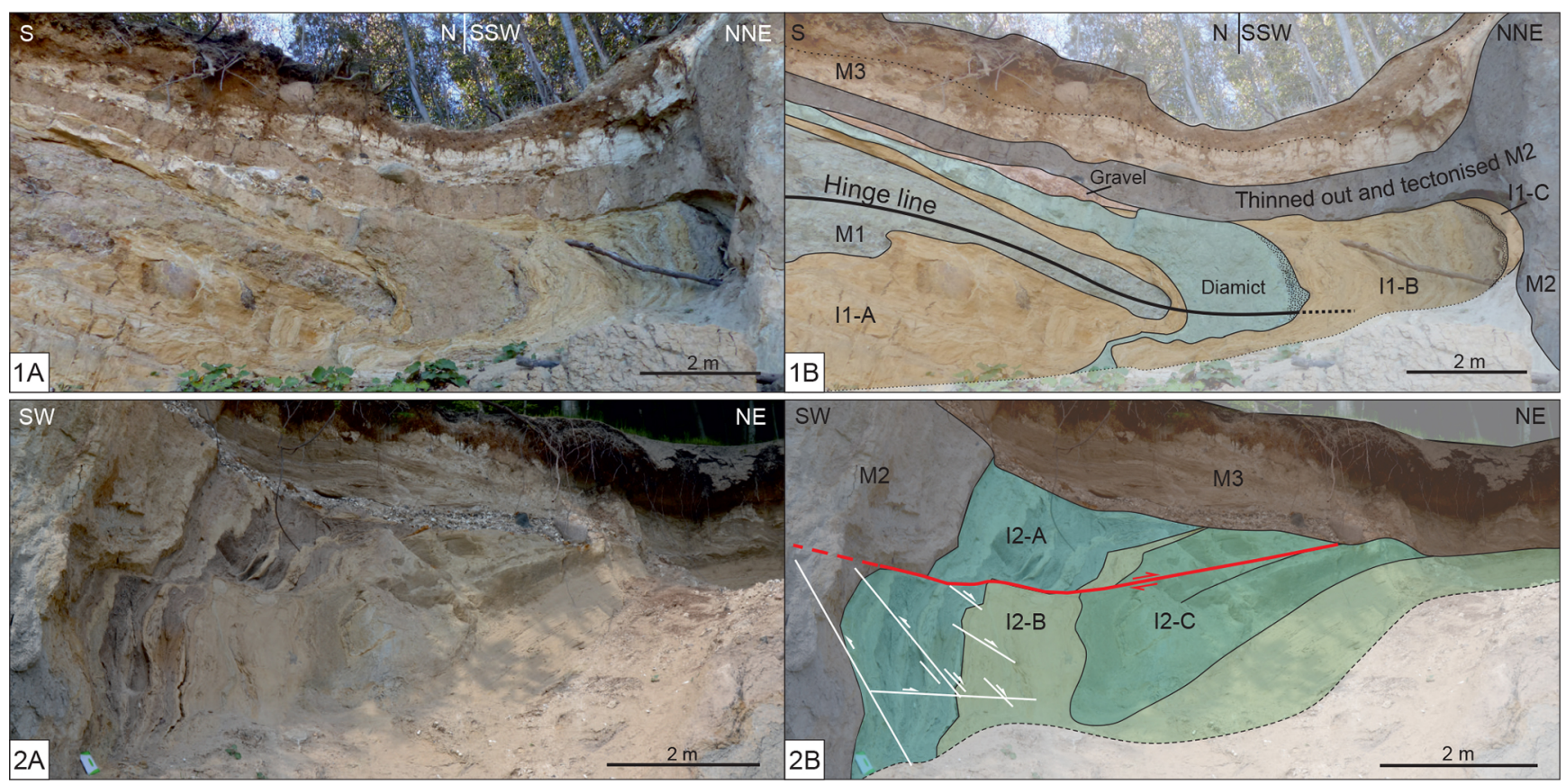

Figure 3. Outcrop details at Pleistocene Stripe 4. Photograph (1A) and sketch (1B) showing a drag fold associated with the angular unconformity at the southwestern limb of the syncline. Also shown is the hinge line (see Fig. 1). Photograph (2A) and sketch (2B) show the SW-dipping thrust fault. Note the distinct angular unconformity below the M3 sediment complex, which truncates the older units.

uppermost ends towards the SW and pinch out laterally over a distance of a few metres. The drag fold shows a nearly horizontal axial plane. Measurements along the hinge line (Fig. 1, top left) document a NW-SE-trending fold axis, gently plunging NW (linear 332/07). A glacial diamict (M3 unit) directly overlies the upper limb of the drag fold.

\subsection{Microstructural mapping of till units}

Thin-section-based mapping of clast microfabrics (Phillips et al., 2011) defined by the preferential alignment of detrital grains reveal the presence of up to four different till microfabrics (labelled S1 to S4) within these units. They can best be exemplified in vertical thin sections oriented parallel to the ice flow (Fig. 4). Directional data from thin sections - obtained from the M1 and M2 units - were reoriented according to subsequent glacitectonic tilt and folding. The majority reveal two dominant till fabrics; a planar S1 microfabric dipping at a low to moderate angle towards the NNE (i.e. "up-ice") and a linear S2 fabric plunging at a moderate angle towards the SSW (i.e. "down ice") (Brumme, 2015; Mehlhorn, 2016; Winkler, 2016; Grabbe, 2017). These fabrics, which formed early at the glacier bed during deposition, are cut by the later, subvertical to steeply inclined S3 and S4 fabrics (Fig. 4).

\section{Interpretation of deformational events and kinematic frame}

\subsection{Formation of the NE-verging syncline and second-order anticline: large-scale glacitectonic folding and imbrication}

Both the NW-SE-trending syncline and the subordinate second-order anticline (Fig. 1) exemplify structure and kinematics of the exposed portion of the Jasmund Glacitectonic Complex. Stripe 4 is located within the proximal zone of the southern sub-complex interpreted as an imbricate fan, featuring large-scale folding, particularly revealing distinct footwall synclines below moderately to steeply inclined thrust faults (Gehrmann et al., 2019). Based on cross-section restoration, Gehrmann (2018) deduced the decollement level at a depth of $105-120 \mathrm{~m}$ b.s.l. and calculated a horizontal shortening of about $40 \%(\sim 400 \mathrm{~m})$ in minimum for this sector (complex IV-1 to IV-3) (Fig. 2). The asymmetric geometry and vergence of the tight fold indicate a NE-directed growth of the imbricate thrust stacks at this location within the glacitectonic complex. The documented values correspond to the orientation of the syncline in the best-fit model constructed by Gehrmann (2018). 


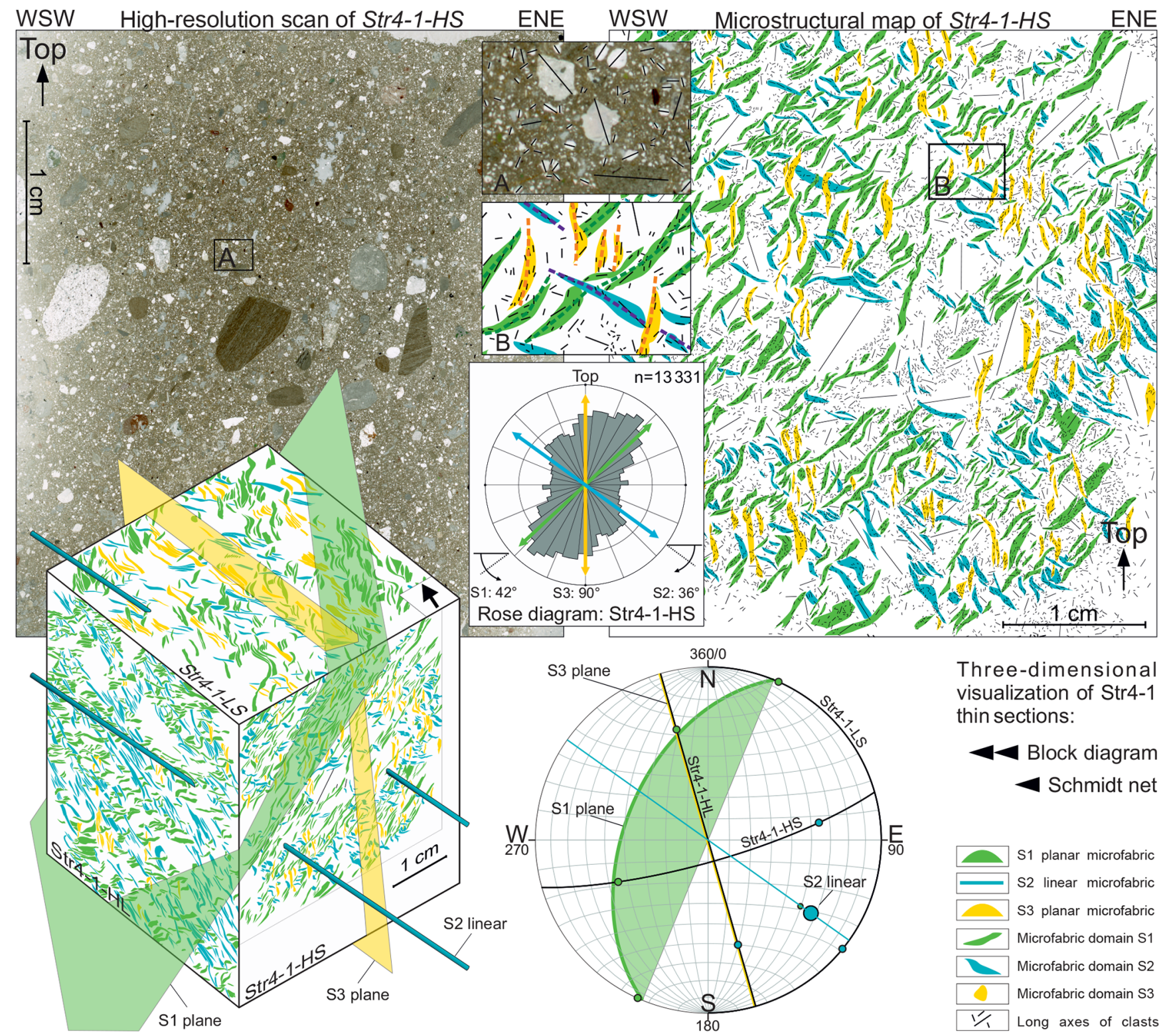

Figure 4. High-resolution scan and microstructural map of a thin section - Str4-1-HS - of sample Str4-1 (see Fig. 1 for sample location), exemplifying the microstructural mapping approach and till microfabric analysis following the methodology of Phillips et al. (2011). The orientation of the long axes of intra-diamict sand- to granule-sized clasts are shown by a rose diagram, stereogram (Schmidt net) and block diagram. Compare stereogram in Fig. 1 for restored data. Note the crosscutting relationship of at least three microfabric domains: the dominant planar fabric (S1) dips in a NNE direction (007/41, reoriented for glacitectonic tilt and folding) and is intersected by a linear fabric (S2) plunging towards the SSW (181/37, reoriented for glacitectonic tilt and folding). Both the planar S1 and linear S2 fabrics are related to subglacial deformation during deposition of the M1 till; their opposing orientations ("up-ice" versus "down-ice") indicate a sense of shear from the NNE to SSW, confirming findings by Brumme (2015). A later subvertical planar fabric (S3), trending NNW-SSE (075/89), cuts across these earlier fabrics. As this (youngest) fabric runs parallel to Str4-1-HL and corresponds with the axial surface of the large-scale syncline, it is thought to have formed by upward escape of porewater through the sediment induced by glacitectonic folding (see Gehrmann et al., 2017). 


\subsection{Origin of the SW-oriented drag fold: glacitectonite formed during deposition of the M3 unit}

The recumbent drag fold below the angular unconformity at the base of the M3 unit (Fig. 3 1A/1B) can be best explained as part of a glacitectonite unit formed by subglacial deformation imposed by ice advancing from the NE. Although subglacial shearing folded and streamlined the pre-existing sediments (M1, I1 and M2), they retained some structural characteristics of their parent material (e.g. cross lamination in the I1 unit). The structural unit is thus classified as a type B glacitectonite (Benn and Evans, 1996), which has undergone largely non-penetrative deformation. The NW-SE-trending hinge line of the fold, the horizontally oriented upper limb and the thinning out of sedimentary beds away from the hinge zone all indicate drag by ice shear towards the SW.

The overlying M3 unit features a combination of erosional channel structures, glacigenic diamicts, and interbedded water-lain gravels and sands (Fig. 1). All sediments deposited above the unconformity contain large amounts of flint pebbles and chalk (granules and fine-grained mud).

\subsection{Fabric development during deposition of the M1 (and M2) diamicts: subglacial formation of a traction till with polyphase deformation}

The analysis of microstructures observed in thin sections obtained from glacial diamicts on Jasmund revealed a relative chronology of deformational events, which can be interpreted in the context of syn-depositional till-forming processes and subsequent post-depositional modification (Brumme, 2015; Brumme et al., 2019). In accordance with these results, clear evidence of subglacial deformation reveals the presence of a pervasive set of clast microfabrics within the M1 and M2 diamicts at Stripe 4 (Mehlhorn, 2016; Winkler, 2016; Grabbe, 2017), documenting polyphase deformation processes at the glacier bed (e.g. van der Meer, 1993; Phillips et al., 2018). Most of these fabrics predate the large-scale glacitectonic folding; i.e. their orientation cannot be related to established ice-flow directions until restoring their original position by rotation and back-tilting (Figs. 1, 4). The two dominant gently dipping clast microfabrics S1 and S2, exemplified within the M1 unit (Fig. 4), display preferred grain orientations towards the NNE (S1) and SSW (S2), respectively, as a result of shear at the glacier bed under ductile conditions (Brumme, 2015). The subvertical to steeply inclined S3 and S4 fabrics are thought to have developed during dewatering of the water-saturated diamicts. A more detailed description and interpretation of the polyphase deformation recorded by the till microfabrics are given by Brumme (2015) and Brumme et al. (2019).

\section{Conclusion}

The origin of the documented clast microfabrics within the glacial diamicts of units M1 and M2 are related to subglacial shear conditions during the advance of the Scandinavian Ice Sheet from the NNE (and NE). The presence of up to four microfabrics (labelled S1 to S4) results from polyphase deformation during till accumulation and penecontemporaneous (to post-depositional) dewatering. Subsequent largescale glacitectonic folding and imbrication produced the NEverging syncline together with the second-order anticline and thrust faults as part of the formation of the southern subcomplex within the Jasmund Glacitectonic Complex. The SW-oriented drag fold associated with the angular glacitectonic unconformity represents the shear-folded base (glacitectonite) of the deformational layer formed during deposition of the M3 till due to ice advance towards the SW; thus, its development postdates the large-scale folding and imbrication at Stripe 4.

Data availability. All underlying data are published in the figures of this article. Thin sections are stored in the thin section archive of the Institute of Geography and Geology at the University of Greifswald.

Author contributions. PM, LW and FCG carried out field work and processed, measured and analysed the samples. PM wrote the first draft of the paper and developed most of the illustrations. MK suggested the field site and joined the sampling. HH and MK designed the project, secured funding and supervised PM, LW and FCG during their bachelor theses. HH rewrote part of the paper. AG and HR contributed with text about the sampling site and the regional geology. All authors contributed to the discussion and interpretation of the presented research results.

Competing interests. The authors declare that they have no conflict of interest.

Acknowledgements. The authority of the National Park "Vorpommersche Boddenlandschaft" kindly granted the approval to work in the Jasmund district. We are grateful to Sylvia Weinert (University of Greifswald) for careful preparation of the thin sections. Martin Meschede and an unknown colleague are thanked for their constructive reviews. We acknowledge support for the article processing charge from the DFG (no. 393148499) and the Open Access Publication Fund of the University of Greifswald.

Financial support. This research has been supported by the DFG (German Research Foundation, grant no. 393148499) and the Open Access Publication Fund of the University of Greifswald. 


\section{References}

Benn, D. I. and Evans, D. J. A.: The interpretation and classification of subglacially-deformed materials, Quaternary Sci. Rev., 15, 23-52, https://doi.org/10.1016/0277-3791(95)00082-8, 1996.

Brumme, J.: Three-dimensional microfabric analyses of Pleistocene tills from the cliff section Dwasieden on Rügen (Baltic Sea Coast): Micromorphological evidence for subglacial polyphase deformation, $\mathrm{PhD}$ thesis, University of Greifswald, Greifswald, Germany, 250 pp., 2015.

Brumme, J., Hüneke, H., and Phillips, E.: Micromorphology and clast microfabrics of subglacial traction tills at the sea-cliff Dwasieden: evidence of polyphase syn- and post-depositional deformation, DEUQUA Spec. Pub., this volume, 2019.

Gehrmann, A.: The multi-stage structural development of the Upper Weichselian Jasmund glacitectonic complex (Rügen, NE Germany), PhD thesis, University of Greifswald, Greifswald, Germany, 235 pp., 2018.

Gehrmann, A. and Harding, C.: Geomorphological Mapping and Spatial Analyses of an Upper Weichselian Glacitectonic Complex Based on LiDAR Data, Jasmund Peninsula (NE Rügen), Germany, Geosciences, 8, 208, https://doi.org/10.3390/geosciences8060208, 2018.

Gehrmann, A., Hüneke, H., Meschede, M., and Phillips, E. R.: 3D microstructural architecture of deformed glacigenic sediments associated with large-scale glacitectonism, Jasmund Peninsula (NE Rügen), Germany, J. Quaternary Sci., 32, 213 230, https://doi.org/10.1002/jqs.2843, 2017.

Gehrmann, A., Meschede, M., Hüneke, H., Pedersen, S. A. S.: Sea cliff at Kieler Ufer (Pleistocene stripes 11-16) - Large-scale architecture and kinematics of the Jasmund Glacitectonic Complex, DEUQUA Spec. Pub., this volume, 2019.

Grabbe, F.-C.: Fazies- und Strukturanalyse des glazitektonisch mehrphasig deformierten M2-Tills vom Streifen 4 auf Jasmund (Rügen), BSc thesis, University of Greifswald, Greifswald, Germany, 48 pp., 2017.

Groth, K.: Zur glazitektonischen Entwicklung der Stauchmoräne Jasmund/Rügen, Schriftenreihe des Landesamtes für Umwelt, Naturschutz und Geologie Mecklenburg-Vorpommern, 3, 39-49, 2003.

Jaekel, O.: Neue Beiträge zur Tektonik des Rügener Steilufers, Zeitschrift der Deutschen Geologischen Gesellschaft, 69, 81$176,1917$.
Kahlke, R.-D.: Verbreitung, Aufbau und Genese der I2Ablagerungen der Halbinsel Jasmund (Rügen), thesis, Universität Greifswald, Greifswald, Germany, 108 pp., 1982.

Keilhack, K.: Die Lagerungsverhältnisse des Diluviums in der Steilküste von Jasmund auf Rügen, Jahrbuch der Preußischen Geologischen Landesanstalt, 33, 114-158, 1914.

Kenzler, M. and Hüneke, H.: Sea cliff at Glowe: Stratigraphy and absolute age chronology of the Jasmund Pleistocene sedimentary record, DEUQUA Spec. Pub., this volume, 2019.

Kenzler, M., Tsukamoto, S., Meng, S., Frechen, M., and Hüneke, H.: New age constraints from the SW Baltic Sea areaimplications for Scandinavian Ice Sheet dynamics and palaeoenvironmental conditions during MIS 3 and early MIS 2, Boreas, 46, 34-52, https://doi.org/10.1111/bor.12206, 2017.

Ludwig, A. O.: Zwei markante Stauchmoränen: Peski/Belorussland und Jasmund, Ostseeinsel Rügen/Nordostdeutschland - Gemeinsame Merkmale und Unterschiede, E\&G Quaternary Sci. J., 60, 31, https://doi.org/10.3285/eg.60.4.06, 2011.

Mehlhorn, P.: Makro- und mikrostrukturelle Analyse der Pleistozän-Sedimente am Streifen 4 von Jasmund (Rügen), BSc thesis, University of Greifswald, Greifswald, Germany, 64 pp., 2016.

Phillips, E. R., van der Meer, J. J. M., and Ferguson, A.: A new "microstructural mapping" methodology for the identification, analysis and interpretation of polyphaser deformation within subglacial sediments, Quaternary Sci. Rev., 30, 2570 2596, https://doi.org/10.1016/j.quascirev.2011.04.024, 2011.

Phillips, E. R., Spagnolo, M., Pilmer, A. C. J., Rea, B. R., Piotrowski, J. A., Ely, J. C., and Carr, S.: Progressive ductile shearing during till accretion within the deforming bed of a palaeo-ice stream, Quaternary Sci. Rev., 193, 1-23, https://doi.org/10.1016/j.quascirev.2018.06.009, 2018.

Steinich, G.: Endogene Tektonik in den Unter-MaastrichtVorkommen auf Jasmund (Rügen), Geol. Beih. 20, 1-207, 1972.

van der Meer, J. J. M.: Microscopic Evidence of Subglacial Deformation, Quaternary Sci. Rev., 12, 553-587, https://doi.org/10.1016/0277-3791(93)90069-X, 1993.

Winkler, L.: Mikrostrukturelle Analyse des glazitektonisch mehrphasig deformierten M2-Tills vom Streifen 4 auf Jasmund (Rügen), BSc thesis, University of Greifswald, Greifswald, Germany, 54 pp., 2016. 